\title{
CYTOTOXICITY OF METABOLITES PRODUCED BY ENDOPHYTIC FUNGUS CLADOSPORIUM SP. ISOLATED FROM MARINE MACROALGAE ON IN-VITRO MCF-7, HELA, AND DU-145 CELL LINES
}

\author{
ASRI PENI WULANDARI ${ }^{*}$, R. R. INDRY NOVIARIN EXAMINATIONa, MADIHAHa, DESI HARNETI PUTRI HUSPA \\ PONIAH ANDAYANINGSIH ${ }^{a}$
}

aDepartment of Biology, Faculty of Mathematics and Natural Sciences, Padjadjaran University, bDepartment of Chemistry, Faculty of Mathematics and Natural Sciences Padjadjaran University, Jl. Raya Bandung-Sumedang KM. 21, West Java, Indonesia 45363 Email: asri.peni@unpad.ac.id

Received: 07 Feb 2018 Revised and Accepted: 09 Jul 2018

\section{ABSTRACT}

Objective: To investigate the in vitro cytotoxicity effect of the crude ethyl acetate extract of Cladosporium sp. on MCF-7, HeLa, and DU-145 cell lines.

Methods: In vitro cytotoxicity was evaluated by tetrazolium reduction assay. The percentage of cell inhibition was analyzed using probit analysis to obtain $50 \%$ inhibitory concentration $\left(\mathrm{IC}_{50}\right)$. Morphological alteration of the cell lines after exposure with extract was observed under an inverted microscope.

Results: The ethyl acetate extract of the metabolite performed an anticancer activity for cancer cell line MCF-7, HeLa, and DU-145 with IC 50 respectively $8.46 \mu \mathrm{g} / \mathrm{ml} ; 9.87 \mu \mathrm{g} / \mathrm{ml}$; and $98.03 \mu \mathrm{g} / \mathrm{ml}$. The extract shows greater the anticancer activity and has strong antiproliferative on MCF-7 and HeLa cell line than DU-145. Confirmation morphological were observed under the inverted microscope showed a morphological change in cancer cells when incubated with the extract.

Conclusion: From the performed assay, the crude extract of Cladosporium sp. exhibit cytotoxic activity against MCF-7, HeLA, and DU-145.

Keywords: Cytotoxicity, Cladosporium sp., Endophytic, Fungus, MTT assay

(c) 2018 The Authors. Published by Innovare Academic Sciences Pvt Ltd. This is an open access article under the CC BY license (http://creativecommons.org/licenses/by/4.0/) DOI: http://dx.doi.org/10.22159/ijpps.2018v10i8.25181

\section{INTRODUCTION}

Nature has been an important source of novel anti-cancer drug leads, with increasing numbers of new compounds sourced from the marine environment. Macroalgae signify the second largest source of marine fungi after mangrove swamps [1]. Marine fungi have shown promising potential sources of new and proactive products as suggested by the chemical diversity of their secondary metabolites. As it seems that algae and their endophytic microorganism would be a good source of biologically active secondary metabolites [2] which have long been produced as an adaptation for specific functions in nature [3]. Some researchers have been able to isolate endophytic Cladosporum from different plant and macroalgae [4-11]. Inr this study, endophytes Cladosporium sp. was isolated from plant tissue host macroalgae Sargassum cinereum taken from the territorial waters of Pramuka Island, in Indonesia.

The use of crude extracts of metabolite compounds produced by Cladosporium sp. has been shown to show anticancer activity [4]. Testing of several bioactive compounds successfully isolated from Cladosporium spp. such as taxol $[4,5]$, Sporiolides A and B [6], Cladosporilactam A [7], Anhydro-fusarubin, Methyl ether of fusarubin, Cladosporol I and C [8], Cladosporone A [9] can demonstrate the powerful antiproliferative effect of cancer cell lines, thus the potency of metabolite from Cladosporium spp. could be developed as candidates of the anticancer drug.

In this studsy, using the human breast cancer adenocarcinoma cell line (MCF-7) that causes the most death in women has been studied for its sensitivity to metabolites from Clasopdorium [4, 5, 11]. Type of other cancer cell lines cervical cancers (HeLa) that is commonly found in Indonesia. Human prostate cancer cells (DU-145) is the most common type of cancer in the elderly [12]. Both types of cancer cell lines have not reported any effects of proliferation with the use of extracts or active compounds from Cladosiporium spp.

Considering the potency of the medicinal uses of Cladosporium sp., the objective of this study investigates the in vitro cytotoxicity of the crude ethyl acetate extract of metabolite produced by Cladosporium sp. on MCF-7, HeLa, and DU-145 cell lines

\section{MATERIALS AND METHODS}

Fungal material

Cladosporium sp. EN-S01 was isolated from the marine brown algae Sargassum cinereum, collected from Pramuka Island, Kepulauan Seribu Marine National Park, Indonesia. This fungus was identified by morphological features, including the characteristic of ascospores and colonies. The pure cultures were deposited in the Laboratorium of Microbiology, Biology Department, Faculty of Mathematics and Natural Sciences, Universitas Padjadjaran.

\section{Cultivation and extraction}

Cladosporium sp. was cultivated in $1 \mathrm{l}$ Erlenmeyer flask containing saline water, Potato Dextrose Broth, $\mathrm{CaCO}_{3}$, yeast extract, and chloramphenicol. The culture was incubated at $25^{\circ} \mathrm{C}$ for $5 \mathrm{~d}$. The filtered broth was extracted with ethyl acetate then evaporated under vacuum in a rotary evaporator, to give $1 \mathrm{~g}$ of the dark brown viscous mass of the crude ethyl acetate extract.

\section{Cell culture}

Three human cancer cell lines were used to assess anticancer activity. MCF-7, HeLa, and DU-145 cell lines provided by Cell and Tissue Culture Laboratory, Teaching Hospital Universitas Padjadjaran. Human cancer cell lines were maintained as monolayer cultures in RPMI, supplemented with $10 \%$ Fetal Bovine Serum and 1\% of the antibiotic solution under an atmosphere of $5 \% \mathrm{CO}^{2}$ at $37^{\circ} \mathrm{C}$. Cell was trypsinized confluent. A stock solution of crude ethyl acetate extracts of Cladosporium sp. was prepared in $0,1,10,100$, and $1000 \mu \mathrm{g} / \mathrm{ml}$. All the cells were incubated with the extract and dissolved in RPMI just before use, in order to maintain the same condition for all cell lines [13].

\section{Tetrazolium reduction assay}

The effect of anticancer from crude ethyl acetate extracts of Cladosporium sp., algae marine-derived fungus on MCF-7, HeLa, and 
DU-145 cell lines was evaluated through micro-culture tetrazolium assay (MTT) and 2-(2-methoxy-4-nitrophenyl)-3-(4-nitrophenyl)-5(2,4-disulfophenyl)-2H-tetrazolium (WST). In this study, the crude extract was tested in vitro by using WST CCK-8 kit [14], while MTT kit was used for HeLa and DU-145 cell line. In principle, the use of WST reagent works similarly to MTT by reacting with mitochondrial succinic-tetrazolium reductase which forms formazan dyes [15].

The assay was done with plated the cells in 96-multiwell culture plates at a density of $0.8 \times 10^{4}-1 \times 10^{4}$ cells/well. Twenty-four hours after plating, the medium was discarded and fresh medium containing the extract of Cladosporium sp. at different concentrations $(1,10,100$, and $1000 \mu \mathrm{g} / \mathrm{ml})$ and control $(0 \mu \mathrm{g} / \mathrm{ml})$ was added. After $48 \mathrm{~h}$ incubation with extracts, the reagent of WST CCK-8 or MTT kit was added at a final concentration of $0,5 \mathrm{mg} / \mathrm{ml}$ and incubated for $2 \mathrm{~h}$, furthermore, the medium was removed.

To evaluate the effect on cell proliferation, the absorbance at the beginning of incubation was subtracted from all the experimental condition used, including the control. The results are expressed as the percentage of cell proliferation relative to control (untreated cells) carried out in duplicate. Percentage of cell viability (CV) was calculated manually using the formula:
$\%$ Cell Inhibition $=100-$ Abs (sample) $/$ Abs (control) $\times 100$

Positive values (between 0 and 100\%) can be interpreted as inhibition of cell proliferation. A dose-response curve were plotted to enable the calculation of $\mathrm{IC}_{50}$. The $\mathrm{IC}_{50}$ values were determined using Probit Analysis. IC 50 corresponds to the concentration of the extract that decreases the number of viable cells by $50 \%$. In this case, the absorbance in the control corresponds to $100 \%$ viability.

\section{Morphological analysis}

Morphological observation of cell treated with crude ethyl acetate of fermented Cladosporium sp. extract from cytotoxicity study was done to determine the changes induced by the extracts. Morphological alteration such as cell shrinkage, membrane blabbing, rounded ad detached cells were observed for confirmation effect of cell death.

\section{RESULTS AND DISCUSSION}

\section{Antiproliferative effects of MCF-7, HeLa, and DU-145 cell lines}

In vitro cytotoxic activity of Cladosporium sp. ethyl acetate extracts in MCF-7, HeLa, and DU-145 cell lines were cultured in the absence and presence of the crude extract of multiple concentrations. As shown in (table 1).

Table 1: In vitro cytotoxic activity of Cladosporium sp. ethyl acetate extracts in cell lines

\begin{tabular}{llll}
\hline Concentration $(\boldsymbol{\mu g} / \mathbf{m l})$ & \% Cell inhibition & & \\
\cline { 2 - 4 } & MCF-7 & HeLa & DU-145 \\
\hline 0 & 0.00 & 0.00 & 0.00 \\
1 & $31.49 \pm 9.90$ & $32.66 \pm 5.44$ & $6.31 \pm 10.18$ \\
10 & $51.42 \pm 5.25$ & $50.10 \pm 4.39$ & $28.32 \pm 21.82$ \\
100 & $55.18 \pm 0.73$ & $54.34 \pm 1.42$ & $50.24 \pm 6.88$ \\
1000 & $53.07 \pm 4.89$ & $57.99 \pm 3.48$ & $71.14 \pm 5.66$ \\
\hline
\end{tabular}

Result represent mean \pm standar deviation $(\mathrm{n}=3)$

It was observed, the $\mathrm{IC}_{50}$ (concentration of the extract that decreases the number of viable cells by $50 \%$ ) for each cell line was calculated from the dose-response curves (fig. 1-3). The crude extract of ethyl acetate exhibited significant activity against the MCF-7 and HeLa cell line with an $\mathrm{IC}_{50}$ values of $8.4 \mu \mathrm{g} / \mathrm{ml}$ and $9.87 \mu \mathrm{g} / \mathrm{ml}$, however, DU145 showed the only $\mathrm{IC}_{50}$ value of $98.03 \mu \mathrm{g} / \mathrm{ml}$. Results showed that the fungal crude extract could significantly inhibit the viability of the cancer cells and have potential anticancer activity.

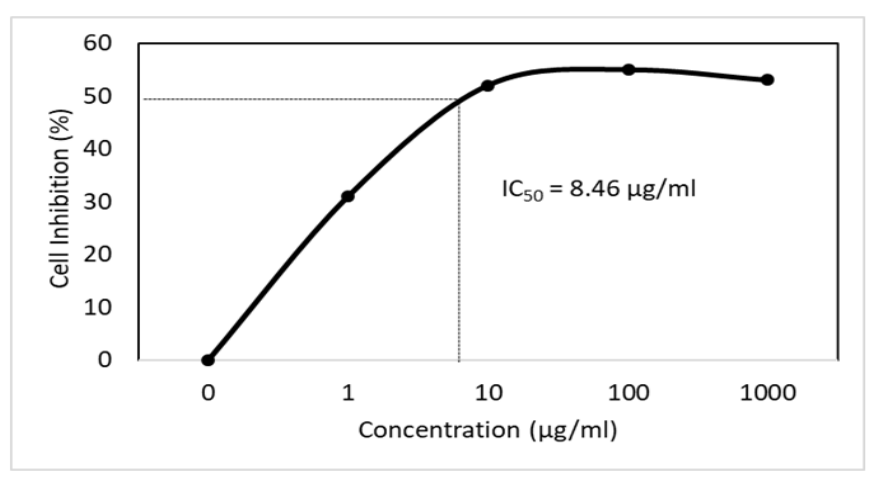

Fig. 1: Effect on antiproliferative of Cladosporium sp. on MCF-7 cell line

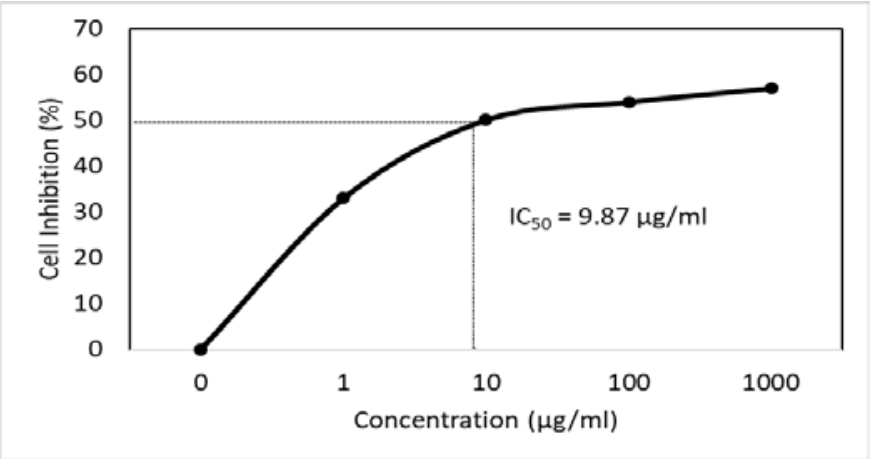

Fig. 2: Effect on antiproliferative of Cladosporium sp. on HeLa cell line 


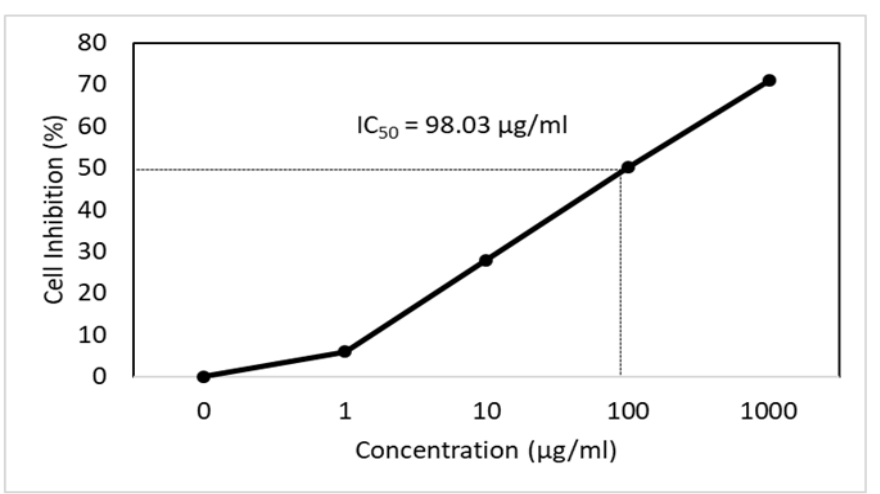

Fig. 3: Effect on antiproliferative of Cladosporium sp. on DU-145 cell line

The reduction in the number of cells was found to suppress the cell proliferation and indicated with has damaged its cell structure. Confirmation by observing the morphological changes of normal cells and their effects after exposure with extracts containing anticancer (fig. 4).

The living MCF-7 and HeLa, and DU-145 cell lines normally observed in epithelial and polygonal shape. Treatment of the cell lines with the ethyl acetate extract of Cladosporium sp. differ the appearance of the normal cells found to be irregular, aggregate, spherical in shape indicating damaged cells and spreading patterns were constrained The in vitro anticancer activity of the extract in MCF-7, HeLa, and DU-145 cells was mainly due to the induction of cell death. The characteristic is common to several chemotherapeutic drugs, which reveal an anticancer activity mainly due to their ability to induce DNA damage; if such DNA damage is not properly repaired, its accumulation ultimately ensues in cell death [16].

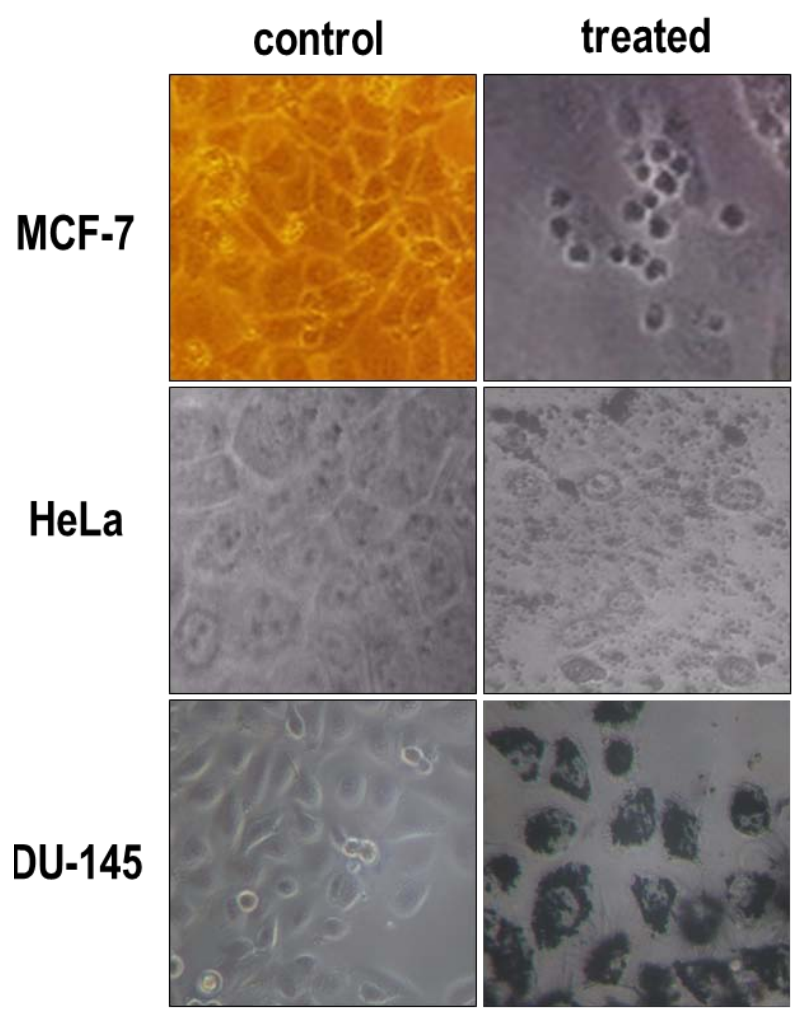

Fig. 4: (a) normal cell lines and (b) morphological alteration at $100 \mu \mathrm{g} / \mathrm{ml}$ (Magnification 100x)

\section{DISCUSSION}

The use of anticancer extracts from Cladosporium spp. have been evaluated in some of the most deadly cancer cell lines, such as colon cell lines (HCT-116 and HCT-15), breast (MCF-7 and T47D), prostate (PC-3), cervix (HeLa), Prostate (DU-145), Mouse lymphocytic leukemia (L1210) and Leukemia (K-562), Lung (A-549 and H446), Hepar (Huh7), Liver (LM3). Table 2 showed cytotoxicity of the compounds and crude extract of metabolite produced by Cladosporium spp.
This study to investigate the cytotoxicity of the crude extract of metabolite produced by Cladosporium sp. in vitro MCF-7, HeLa, an DU145 cell lines. Similar studies using plant were reported. IC $_{50}$ of Monarda citriodora on colon (HCT-116), breast MCF-7, prostate (PC-3) cell lines were $<10 \mu \mathrm{g} / \mathrm{ml}$. The present study contributes to evidence that the metabolites produced by endopytic fungus Cladosporium $s p$. isolated from marine macroalgae have potential anticancer activity on in-vitro MCF-7, HeLa, and DU-145 cell lines. Furthermore, this study is the first that evaluates antiproliferative effects on cell lines cervical cancers (HeLa) from a crude extract of Cladosporium sp. 
Tabel 2: Cytotoxicity of the compounds and crude extract of metabolite produced by Cladosporium spp

\begin{tabular}{|c|c|c|c|c|c|c|}
\hline Species & $\begin{array}{l}\text { Endophytic } \\
\text { source }\end{array}$ & Solvent & Compound & Cell line & IC 50 & Ref. \\
\hline C. tenuissimum & $\begin{array}{l}\text { Plant } \\
\text { Monarda citriodora }\end{array}$ & $\begin{array}{l}\text { Methylene } \\
\text { chloride }\end{array}$ & Crude extract & $\begin{array}{l}\text { Colon (HCT-116) } \\
\text { Breast (MCF-7) } \\
\text { Prostate (PC-3) }\end{array}$ & $\begin{array}{l}<10 \mu \mathrm{g} / \mathrm{ml} \\
<10 \mu \mathrm{g} / \mathrm{ml} \\
<10 \mu \mathrm{g} / \mathrm{ml}\end{array}$ & [4] \\
\hline Cladosporium sp. & Marine macroalga Sargassum cinereum & Ethyl acetate & Crude extract & $\begin{array}{l}\text { Breast (MCF-7) } \\
\text { Cervix (HeLa) } \\
\text { Prostate (DU- } \\
145)\end{array}$ & $\begin{array}{l}8.46 \mu \mathrm{g} / \mathrm{ml} \\
9.87 \mu \mathrm{g} / \mathrm{ml} \\
98.03 \mu \mathrm{g} / \mathrm{ml}\end{array}$ & This study \\
\hline C. oxysporum & $\begin{array}{l}\text { Plant } \\
\text { Moringa oleifera }\end{array}$ & $\begin{array}{l}\text { Dichloro- } \\
\text { methane }\end{array}$ & Taxol & $\begin{array}{l}\text { Colon (HCT-15) } \\
\text { Breast (T47D) }\end{array}$ & $\begin{array}{l}3.5 \mu \mathrm{M} \\
2.5 \mu \mathrm{M}\end{array}$ & [5] \\
\hline Cladosporium sp. & Marine macroalga Actinotrichia fragilis & Ethyl acetate & $\begin{array}{l}\text { Sporiolides A } \\
\text { Sporiolides B }\end{array}$ & $\begin{array}{l}\text { Mouse } \\
\text { lymphocytic } \\
\text { leukemia (L1210) }\end{array}$ & $\begin{array}{l}0.13 \mu \mathrm{g} / \mathrm{ml} \\
0.81 \mu \mathrm{g} / \mathrm{ml}\end{array}$ & {$[6]$} \\
\hline Cladosporium sp. & Coral, Anthogorgia ochracea & Ethyl acetate & $\begin{array}{l}\text { Cladosporilactam } \\
\text { A }\end{array}$ & HeLa & $0,76 \mu \mathrm{g} / \mathrm{ml}$ & [7] \\
\hline Cladosporium sp. & $\begin{array}{l}\text { Plant } \\
\text { Rauwolfia serpentina }\end{array}$ & Ethyl acetate & $\begin{array}{l}\text { Anhydro-fusarubin } \\
\text { Methyl ether of } \\
\text { fusarubin }\end{array}$ & $\begin{array}{l}\text { Leukemia (K- } \\
562) \\
\text { Leukemia (K- } \\
562)\end{array}$ & $\begin{array}{l}3.97 \mu \mathrm{g} / \mathrm{ml} \\
3.58 \mu \mathrm{g} / \mathrm{ml}\end{array}$ & [8] \\
\hline $\begin{array}{l}\text { C. } \\
\text { cladosporioides }\end{array}$ & $\begin{array}{l}\text { Marine macroalga } \\
\text { Laurencia okamurai }\end{array}$ & Ethyl acetate & Cladosporol I & $\begin{array}{l}\text { Lung (A-549) } \\
\text { Hepar (Huh7) } \\
\text { Liver (LM3) } \\
\text { Lung (H446) }\end{array}$ & $\begin{array}{l}5.0 \mu \mathrm{g} / \mathrm{ml} \\
1.0 \mu \mathrm{g} / \mathrm{ml} \\
4.1 \mu \mathrm{g} / \mathrm{ml} \\
4.0 \mu \mathrm{g} / \mathrm{ml}\end{array}$ & [9] \\
\hline Cladosporium sp. & $\begin{array}{l}\text { Mangrove } \\
\text { Kandelia candel }\end{array}$ & Ethyl acetate & Cladosporone A & - & - & {$[10]$} \\
\hline C. oxysporum & - & - & Taxol & Breast (T47D) & $2.5 \mu \mathrm{M} / \mathrm{ml}$ & [11] \\
\hline
\end{tabular}

Cytotoxicity of crude extracts from Cladosporium sp which isolated from the terrestrial plant [17] proved anti-cancer activity with $\mathrm{IC}_{50}$ value was $<10 \mu \mathrm{g} / \mathrm{ml}$. A similar result was obtained in this study, the use of crude extracts from Cladosporium sp. Isolated from marine macroalgae Sargassum cinereum showed toxicity, lower than 10 $\mu \mathrm{g} / \mathrm{ml}$ except for prostate cancer line DU-145 IC 50 . For the best of our knowledge, the application of crude extracts or purifiedcompounds against anticancer prostate line DU-145 cells has not been previously reported. The effectiveness of anticancer to DU-145 cell line is very important to be studied further and needs to be tested by using isolated compounds.

Data from our study can be more convincing for using the ethyl extract to produce the anticancer active compound from Cladosporium spp. The results obtained hence confirm that the fungus has significant anticancer potential as stated in the other reports about the Cladosporium [4-11]. Purification and isolation of anticancer compound from Cladosporium spp. have been studied, some were reported that they are able to increase the effectiveness for inhibiting the growth of cancer cell. Some endophytic Cladosporium genus from plants are known to produce several compounds with the anticancer activity, such as cladosporone [10] and taxol [11]. Shigemori et al. (2004) have reported that isolation of macrolides from endophytic Cladosporium sp. derived brown algae Actinotrichia fragilis, namely, sporiolides A and B. The results showed that sporiolides A and B showed an $\mathrm{IC}_{50}$, respectively, 0.13 $\mu \mathrm{g} / \mathrm{ml}$ and $0.81 \mu \mathrm{g} / \mathrm{ml}$ in L1210 (mouse lymphocytic leukemia) [6]. Cao et al. (2015) have reported the isolation of bicyclic lactam, namely Cladosporilactam A exhibited promising cytotoxic activity against HeLa (cervical cancer cell line) with IC $_{50}$ value of $0.76 \mu \mathrm{g} / \mathrm{ml}$ [7]. Khan et al. (2016) have reported the isolation of naphthoquinones from endophytic Cladosporium sp. derived Rauwolfia serpentine, namely, anhydrofusarubin and methyl ether of fusarubin. The results showed that anhydrofusarubin and methyl ether of fusarubin showed an $\mathrm{IC}_{50}$, respectively, $3.97 \mu \mathrm{g} / \mathrm{ml}$ and 3.58 $\mu \mathrm{g} / \mathrm{ml}$ against K-562 (human leukaemia cells) [8]. Li et al. (2017) reported cytotoxic activity from marine algal-derived endophytic fungus Cladosporium cladosporioides EN-399 compounds. Cladosporol I showed cytotoxicity against A549 (human lung adenocarcinoma), Huh7 (human hepatocarcinoma), and LM3 (human liver cancer) with $\mathrm{IC}_{50}$ values of $5.0,1.0$, and $4.1 \mu \mathrm{g} / \mathrm{ml}$, respectively, and Cladosporium $\mathrm{C}$ showed activity against $\mathrm{H} 446$ (human cell lung cancer) with $\mathrm{IC}_{50}$ value of $4.0 \mu \mathrm{g} / \mathrm{ml}$ [9]. Scientists have been struggling for new methods in which to improve anticancer compound production to meet the drug demand.

\section{CONCLUSION}

In summary, the crude extract of endophytic fungus Cladosporium sp. from marine macroalgae Sargassum cineurem demonstrates a high potential anticancer activity in breast adenocarcinoma (MCF-7), human epithelial carcinoma (HeLa), and human prostate carcinoma (DU-145). Further, investigations will be interesting to find medicinal compound and should focus on isolating the potential molecule which responsible for the activity of anticancer.

\section{ACKNOWLEDGEMENT}

The authors would like to acknowledge Academic Leadership GrantUniversitas Padjadjaran-2017 for providing the necessary funds to conduct the study.

\section{AUTHORS CONTRIBUTIONS}

Conceived and designed the experiments: APW, DH, PA, Performed the experiments: RRINE, Analyzed the data: APW, RRINE, M, Wrote the paper: APW, RRINE

\section{CONFLICTS OF INTERESTS}

All authors have none to declare

\section{REFERENCES}

1. Jones EBG. Marine fungi: some factors influencing biodiversity. Fungal Divers 2000;4:53-73.

2. Schulz B, Boyle C, Draeger S. Endophytic fungi: a source of biologically active secondary metabolites. Mycol Res 2002; 106:996-1004.

3. Strobel GA. Endophytes as sources of bioactive products. Microb Infect 2003;5:535-44.

4. Katoch M, Phull S, Vaid S, Singh S. Diversity, phylogeny, the anticancer and antimicrobial potential of fungal endophytes associated with Monarda citriodora L. BMC Microbiol 2017;17:44.

5. Raj KG, Manikandan R, Arulvasu C, Pandi M. Anti-proliferative effect of fungal taxol extracted from Cladosporium oxysporum against human pathogenic bacteria and human colon cancer cell line HCT 15. Spectrochim Acta Part A 2015;138:667-74.

6. Shigemori H, Kasai Y, Komatsu K, Tsuda M, Mikami Y, Kobayashi J. Sporiolides a and b, new cytotoxic twelve- 
membered macrolides from a marine-derived fungus Cladosporium species. Marine Drugs 2004;2:164-9.

7. Cao F, Yang Q, Shao CL, Kong CJ, Zheng JJ, Liu YF, et al. Bioactive 7-oxabicyclic [6.3.0] lactam and 12-membered macrolides from a gorgonian-derived Cladosporium sp. fungus. Marine Drugs 2015;13:4171-8.

8. Khan MIH, Sohrab MH, Rony SR, Tareq FS, Hasan CM, Mazid MA Cytotoxic and antibacterial naphthoquinones from an endophytic fungus, Cladosporium sp. Toxicol Rep 2016;3:861-5.

9. Li HL, Li XM, Mándi A, Antus S, Li X, Zhang $\mathrm{P}$, et al. Characterization of Cladosporium from the marine algalderived endophytic fungus Cladosporium cladosporioides EN399 and configurational revision of the previously reported Cladosporium derivatives. J Org Chem 2017;82:9946-54

10. Ai W, Lin X, Wang Z, Lu X, Mangaladoss F, Yang X, et al. Cladosporone $a$, a new dimeric tetralone from fungus Cladosporium sp. KcFL6'derived of mangrove plant Kandelia candel. J Antibiot 2015;68:213.

11. Raj KG, Sambantham S, Manikanadan R, Arulvasu C, Pandi M Fungal taxol extracted from Cladosporium oxysporum induces apoptosis in T47D human breast cancer cell line. Asian Pac J Cancer Prev 2014;15:6627-32.

12. Makassari D. Penelitian sumber daya dan pelayanan kesehatan kemenkes RI. Indonesian J Cancer; 2017. p. 1.

13. Freshney RI. Culture of animal cells: a manual of basic technique and specialized applications. 6th ed. US: WileyBlackwell; 2010.

14. Dojindo. com [Internet]. Rockville: Measuring Cell Viability and Cytotoxicity; c2015. Available from: http://at www. dojindo.com/. [Last accessed on 20 Nov 2015].

15. Ngamwongsatit P, Banada PP, Panbangred W, Bhunia AK. WST1-based cell cytotoxicity assay as a substitute for an MTT-based assay for rapid detection of toxigenic Bacillus species using CHO cell line. J Microbiol Methods 2018;73:211-5.

16. Roos WP, Bernd K. DNA damage-induced cell death: from specific DNA lesions to the DNA damage response and apoptosis. Cancer Lett 2013;332:237-48.

17. Haridas R, Manorama S, Thekkan S. In vitro cytotoxicity activity of Malaxis rheedii sw methanol extract against hela cell line and MCF-7 cell line. Asian J Pharm Clin Res 2016;9:1-3. 